\title{
Lifting Travel Ban to Israel from Bangladesh Passport: Law and Diplomacy TÊTE-À-TÊTE
}

\author{
MD Parvez Sattar \\ Department of Law, School of Liberal Arts and Social Sciences, Independent University, Bangladesh, Dhaka, Bangladesh \\ Email: rana@iub.edu.bd, ranapsattar@gmail.com
}

How to cite this paper: Sattar, M. P. (2021). Lifting Travel Ban to Israel from Bangladesh Passport: Law and Diplomacy TÊTE-À-TÊTE. Beijing Law Review, 12, 1109-1130. https://doi.org/10.4236/blr.2021.124057

Received: September 30, 2021

Accepted: December 3, 2021

Published: December 6, 2021

Copyright $\odot 2021$ by author(s) and Scientific Research Publishing Inc. This work is licensed under the Creative Commons Attribution International License (CC BY 4.0).

http://creativecommons.org/licenses/by/4.0/

\begin{abstract}
Bangladesh neither recognizes Israel, nor does it maintain any diplomatic relations with the only Jewish State in the world. In May 2021, in a sudden unsolicited move, the Government of Bangladesh declared that the travel ban to Israel contained in Bangladesh e-passport is now removed. The issue immediately raised several intriguing questions including indications of revisiting Bangladesh's strategic foreign policy regarding Israel. In this backdrop, the present article aims at fleshing out the interface between law and diplomacy regarding questions of regulatory compliance in making the stated change vis-a-vi the politico-legal significance of the move at the regional and global strata. Background information and data are mostly based on desk-based analysis of media reports and articles as both primary and secondary sources as well as researching scholarly texts and commentaries. An assortment of thoughts and speculations around the subject have been critically analysed leading to the key finding of the paper that notwithstanding the diversity of political delineation and bureaucratic explications from the Government, "lifting" the travel ban carries significant foreign policy and diplomatic implications for Bangladesh in its present and future relations with Israel. The paper concludes with a note that the complexities arising out of the issue and their absorbing global attention render the Bangladesh-Israel travel ban controversy a textbook case in both legal and diplomatic studies that call for further investigation and research.
\end{abstract}

\section{Keywords}

Israel Travel Ban, Law and Diplomacy, Israel-Palestine Conflict, Bangladesh-Israel Relations, Bangladesh Foreign Policy, Legitimacy and Impact 


\section{Introduction}

An outcome of the Allied victory in the World War I outlasting the Central Powers was the dismantling of the 400-year Ottoman Empire (1517-1917) and the Great Britain's taking control over the region in the Western and Middle-Eastern Asia that was part of the Ottoman Syria for 300 years, a part of which eventually became known as Palestine. This is the region that in the vicious trajectory of a complex geo-political hegemony of power, dominance and global leadership emerged as the Jewish State of Israel (Hebrew Medinat Yisra'el), Palestine and Jordan.

The word Palestine derives from Philistia, the name given by Greek writers to the land of the Philistines, who in the 12th century BCE inhabited a small area of land on the eastern coast of the Mediterranean Sea, between today's Tel Aviv-Yafo and Gaza, also known as the Gaza Strip (Faris, Fraser, Kenyon, et al., 2021). Gaza presently homes about 2 million Palestinians, many of them displaced after leaving or being driven from Israel during the 1948-49 Arab-Israel War (termed by many as the Israeli War of Independence). On 15 May each year, people of Palestine commemorates the day of Catastrophe, referred to as Al-Nakba, that they lost their land and forced by the Israeli Occupation Forces to take refuge in the neighbouring Jordan, Syria and Lebanon.

However, this article is not intended to revisit the dichotomous fallacies of the complex geo-politics in the region, or the sorry story of the people of Palestine expelled, evicted and forced into an endless misery of violent conflicts and oppression by the squatting Israeli authorities for over seven decades that continue to-date. Instead, the limited scope of the paper is to review the legal implications and foreign policy impact of a recent initiative by the Government of Bangladesh (GoB) removing the phrase "all countries except Israel" from the passports issued for its citizens that prohibited a holder of the passport from travelling to Israel.

In consequence of the change stated above, the new electronic passports (e-passports) of Bangladesh will now mention: "This passport is valid for all countries of the world". In fact, being the first country in South Asia to introduce the e-passport (also known as biometric or digital passport), Bangladesh has already acted on this revised policy since the end of 2020 but without having made any public announcement in this regard (Star Digital Report, 2021a). The issue came to domestic (including the GoB) and international attention following a twitter issued by an Israeli Ministry of Foreign Affairs official, published on the Jerusalem Post, welcoming Bangladesh for lifting the travel ban to Israel (The Jerusalem Post, 23 May 2021).

In addition to creating confusions and public uproars in the South Asian Muslim-majority nation of 166 million, the stated move by the GoB has raised questions of legitimacy and its complaisance with Bangladesh's long-held commitments and solidarity with the causes of the people of Palestine since the independence of the country in 1971. The debates around the issue have been fur- 
ther heated up by the timing of the move that witnessed the deaths of hundreds of Palestinians in the Israeli bombing of the Gaza Strip during the month of Nakba and Ramadan in 2021 amidst criticism and ceasefire efforts by the UN and other international actors. Finally, being a member of the Organisation of Islamic Cooperation (OIC) and a close strategic ally of the Arab League, Bangladesh's foreign policy bears significant impact on the collective Asian approach (or at least a large part of it) to the enduring Arab-Israel issues including the future of an independent Palestinian State under the UN-backed "two-state solution" (Britannica, 2021).

Accordingly, the present paper is organized into three focal premises. First, it addresses the issue of removing the phrase "except Israel" from the national passports of Bangladesh from two correlated perspectives: firstly, what are the legal bases for the executive action that has multifaceted impact on the people of Bangladesh and, technically, whether the Government action complied with the required procedural steps under the laws of the land. The second relates to questions and concerns emanating from issues involving the country's discreet foreign policies and broader international relations, including bi- and multilateral trade and economy, strategic arrays and diplomatic astute in relation to the increasingly complex multiplexity of global geo-politics, the long-standing Middle-East issue in particular. Finally, the third section purports to shed light on the intriguing question of possibilities of opening up windows for eventual development of a softened approach by Bangladesh that includes recognizing the State of Israel and adopting strategic flexibility in siding with the seemingly insurmountable border-stance held by Palestine and its Arab allies.

The paper concludes with a note in support of its key contention that notwithstanding the diversity of political delineation and bureaucratic explications from the Government of Bangladesh as to the "lifting" of the travel ban (such as maintaining international standards, or simply a matter of "administrative convenience", etc.), some of which contextually contradict each other, the move carries significant foreign policy and diplomatic implications. While being a sovereign independent State, Bangladesh is fully entitled to make (or change) its foreign policy strategies, any such move and actions are expected to be made in compliance with standard regulatory requirements and procedural framework to endow them with internal legitimacy as well as external credibility at the global stratum.

\section{Legal Basis of Removing the Travel Ban}

The following section examines the legitimacy and procedural compliance in removing the two-word phrase ("except Israel") by the GoB from its national passports. The paper identifies existing legal and regulatory provisions in Bangladesh relating to the policy move, including prosecuting anyone acting in contravention of the changed statement in the passport.

A quick review of existing statutory and other regulatory provisions (Acts, 
Ordinances, Rules and Orders) depicts that there are numerous legal instruments that relate to or deal with passport and immigration in Bangladesh while only three of them relate to overseas travel authorization and required travel documents for the nationals of the country. These are: Bangladesh Passport Rules, 1974 that provides rules relating to types, issuing authorities, format, requirements, etc. of Bangladesh passports; The Bangladesh Passport Order, 1973 that prescribes rules regarding issuance, possession, use and compliance with the passport regulations; and The Passport Act, 1920 that deals with the power to require passports of persons entering Bangladesh and empower the prescribed authority to make passport-related rules (Ministry of Law, Justice and Parliamentary Affairs, n.d.).

From an analysis of the three pertinent laws stated above, it is apparent that the prohibition on travel to Israel as existed in Bangladesh passports until now was made by the Government under the Bangladesh Passport Order, 1973. Section 14(d) of the Order provides:

Upon the issue of a notification by the Government that a foreign country is ... a country to which travel must be restricted in the public interest because such travel would seriously impair the conduct of foreign affairs of the Government, a passport or travel document for travel through or visiting such country shall cease to be valid for such travel or visit unless in any case a special endorsement in that behalf is made by the prescribed authority.

On the other hand, the Government move to make the change in the newly issued e-passports removing the two words ("except Israel") prohibiting travel to Israel has been made under section 4(1) of the Bangladesh Passport Order, 1973 that provides that "the conditions subject to which and the forms in which a passport or a travel document shall be issued ... shall be as may be prescribed." The same Order further provides that the passport authority may "issue passport or travel document, as the case may be, or refuse to issue passport or travel document or restrict the number of countries to be endorsed upon such passport or travel document." In the given circumstance, removal of the two-words is being applied only to the newly issued e-passports, while the already existing Machine Readable Passports (MRP) that contains the phrase would remain valid until the date of their expiry.

It may be noted that similar changes in Bangladesh passports were made previously on two occasions. Until 1994, Bangladesh passports contained a travel prohibition clause to South Africa, Taiwan and Israel. However, in 1994, following the abolition of the apartheid in South Africa and the end of global boycott (except by a few Western colonial powers), travel ban on South Africa was removed by Bangladesh Government from the then hand-written, traditional passports. The second occasion was a rather quiet and inconspicuous dropout of the ban on Taiwan in 2004, allegedly due to extensive lobbying by some business groups, although Bangladesh still has no official diplomatic relation with Taiwan (Wikipedia, 2021). 
Section 3 of the Bangladesh Passport Order, 1973 provides that "No person shall depart or attempt to depart from Bangladesh unless he holds a valid passport or travel document". Hence, "validity" of the passport (or other travel document) is a key requirement for travelling abroad. If the Government makes a rule or order to the effect that the passport-holder is prohibited from travelling to a certain destination (Israel in this case), an attempt to travel to any such destination renders the passport invalid for the purpose of that particular travel. Contravention of this provision (an actual travel, or an attempt to do so) has been made punishable with imprisonment under the Order.

Regarding the official procedure for making any rules or directives relating to changes in the terms and conditions of the passport, Article 17(1) of the Bangladesh Passport Order, 1973 provides that "The Government may, by notification in the official Gazette, make rules for carrying out the purposes of this Order". Again, Section 8 of the Passport Rules, 1974 provides that "[A] passport or travel document shall be issued in such form as the Government may direct".

In addition to the Order, 1973 and the Rule, 1974, The Passport Act, 1920 also empowers the Government to make rules relating to passports. Section 2(2)(b) of the Act stipulates that the Government may "prescribe the authorities by whom passports must have been issued or renewed, and the conditions with which they must comply." As to the procedural requirement for making any such rules, Section 3(4) provides that all rules made under this section "shall be published in the official Gazette, and shall thereupon have effect as if enacted in this Act." The relevance of the Passport Act, 1920 may be found in an event when a Bangladesh passport-holder travels to Israel from a third country and returns to Bangladesh that would amount to a contravention of the Passport Order and the Rule, and punishable accordingly.

The Government of Bangladesh has clarified that its recent initiative in removing the prohibition clause from the new passports has no impact or change from the previous position that rendered the passport invalid for travelling to Israel. However, from an analysis of the legal provisions stated above, it is evident that the Government is required by law to issue an official Gazette Notification to the effect that all Bangladesh passports will be issued, or renewed, subject to the condition that the holder of the passport shall be prohibited from travelling to Israel irrespective of whether or not such prohibition clause is included in the passport, and that any such travel or attempt will be treated as a culpable offence. None of the concerned government agencies (Ministry of Home or Foreign Affairs) has mentioned about issuing any such notification in the official Gazette of the GoB.

Another pertinent issue relates to the question of which government agency is responsible to issue this notification. Primarily, it should be the agency responsible for issuing passports in Bangladesh, i.e. the Immigration and Passport Branch of the Ministry of Home Affairs (MoHA). As per Rule 3 of the Bangladesh Passport Rules, 1974 "international passports for travel to any foreign country" (and other types of passports or travel documents) shall be issued by 
the Secretary, Ministry of Home Affairs and the Director General, Immigration and Passports, while diplomatic passports may be issued by the Secretary, Ministry of Foreign Affairs or an officer authorized by him. However, considering the fact that the issue here is not the validity of the passport as such but rather the legality of travelling to a particular foreign country, one that involves Bangladesh's foreign policy and the Government's strategic decision, it is believed that an official notification to this effect may also be issued by other concerned Ministries, including the Ministry of Foreign Affairs (MoFA) or the Ministry of Law, Justice and Parliamentary Affairs (MoLJPA).

It may be noticed here that the removal of the two-word phrase (except Israel) is only implemented for the new e-passports, while the large number of existing machine readable passports (MRP), which will remain valid up to the date of their expiry and eventually replaced by e-passports, still contain the prohibition clause. Does this mean that lifting the travel ban is only applicable for the new e-passports and not the MRPs? Logically, that is not the case. Hence, the critical factor here is the policy adopted by the Government of Bangladesh and not the wording of the passport qualifying the countries for which the document shall be valid for travel. This provision is clearly enumerated in the Bangladesh Passport Order, 1973 that provides that up on the issue of a notification by the Government that a foreign country is “... a country to which travel must be restricted in the public interest because such travel would seriously impair the conduct of foreign affairs of the Government, a passport or travel document for travel through or visiting such country shall cease to be valid for such travel or visit unless in any case a special endorsement in that behalf is made by the prescribed authority". Accordingly, the above arguments collectively re-enforce the procedural requirement (stated above) of issuing a formal notification in this regard and make it public by publishing in the Government Gazette.

On 26 May 2021, the Foreign Minister of Bangladesh Dr. AK Abdul Momen said that Bangladeshis will be prosecuted if they travel to Israel: "[I]f anyone goes there without government permission that person is liable to be prosecuted and it has happened before" (bdnews24.com, 2021a). It is not, however, clear from the statement under which specific penal or administrative law of the country such actions will be taken-whether the scanty punitive sanctions provided by the Passport Order, 1973 (discussed above), or other harsher charges under the Penal Code of the country, such as sedition or treason.

Apparently, the Foreign Minister's statement refers to the prosecution and punishment of a Bangladeshi journalist for his attempted travel to Israel in 2003. In that much discussed case, a Dhaka court sentenced Salah Uddin Shoaib Choudhury, controversial editor of the obscure "anti-Jihadist" tabloid The Weekly Blitz, to an extended jail term of seven years on sedition charges under section 505(A) of the Penal Code for carrying documents provoking interreligious friction (Tipu, 2014). He was also charged with treason and blasphemy. He was arrested at Dhaka airport and prosecuted for trying to go to Tel Aviv via Bangkok to present a conference paper on the emergence of Islamic militancy in 
Bangladesh.

In the present context, it has been noted in a recent research that the common law notion of passports "as a tool of national security" (such as in the United Kingdom, Canada, Australia and New Zealand) where "passports remain regulated by, and are issued under, prerogative powers", represents a denial of rights of people (Scott, 2020). In an earlier work, it was noted that "[T] he right to enter one's country, to stay in a country which one has legally entered, and to leave any country including one's own, have been perceived as basic since the Universal Declaration of Human Rights was adopted in 1948...The rights of entry, sojourn, and exit are indivisible: the denial of any one makes the assertion of the others a chimera rather than a reality" (Council of Europe, 2013). On the other hand, however, this right of free movement, inscribed in most major human rights instruments, is subject to lawful restrictions by the states concerned on grounds of necessity and national policies "subject to a proportionality test" (ibid.).

The above stated arguments essentially lead to the question whether the move by the Government of Bangladesh lifting the travel ban phrase ("except Israel") from its new national passports is founded on a change of the country's long-standing foreign policy paradigm and broader diplomatic stance relating to the Israel-Palestine issue as well as the impact of introducing the change. These aspects have been addressed in the following section of the paper.

\section{Foreign Policy Impacts of Lifting the Travel Ban}

\subsection{Lifting Israel Travel Ban: An "Intriguing" Question of Foreign Policy}

Foreign policy is "a direct reflection of a country's traditional values and overall national policies, her aspirations and self-perception" (Ahmed, 2020). According to Otto von Bismarck, the $19^{\text {th }}$ century German statesman and foreign policy icon, "the extension of domestic policy is foreign policy" (Referenced in Fahad, 2021). Foreign policy thus "indicates that type of decisions or collection of activities by any state which is involved with the relation of state or states with that state" (Frankel, 1963).

The fundamental notions of Bangladesh's foreign policy are founded upon the basic premises of "promotion of international peace, security and solidarity". These principles are enumerated in Article 25 of the Constitution of the Peoples' Republic of Bangladesh that provides:

The State shall base its international relations on the principles of respect for national sovereignty and equality, non-interference in the internal affairs of other countries, peaceful settlement of international disputes, and respect for international law and the principles enunciated in the United Nations Charter.

Based on the principles stated above, Article 25 further provides that "the State shall-1) Strive for the renunciation of the use of force in international relations and for general and complete disarmament; 2) Uphold the right of every 
people freely to determine and build up its own social, economic and political system by ways and means of its own free choice; and 3) Support oppressed peoples throughout the world waging a just struggle against imperialism, colonialism or racialism."

It may be noted that the original Article 25 of the 1972 Constitution included a second clause stating that the State shall endeavour "to consolidate, preserve and strengthen fraternal relations among Muslim countries based on Islamic solidarity." Reviving the Constitution's fundamental principle of "secularism and freedom of religion", the stated provisions of Article 25(2) were omitted in 2011 by the much tendentious Fifteenth Amendment of the Constitution. The amendment also removed the words "absolute faith and trust in Allah" from the Constitution, although Islam as the state religion was still kept (with some qualifications, such as that "other religions may be practiced in peace and harmony in the Republic") and "Bismillah-Ar-Rahmani-Rahim" ("in the name of God, the merciful and compassionate") was retained above the Preamble (Yeasmin, n.d.).

However, focusing back on the specific concern of this paper, it is to be noted that Bangladesh maintains a close bilateral relation with Palestine since her independence in 1971. The country has been supporting the Palestinian campaign for an independent state and expressing protests at various international fora against "illegal" Israeli occupation of Palestinian land by Israel as well as continued military escalation, rampant violence, forced eviction and other gross violation of human rights against the people of Palestine. Consequently, Bangladesh neither recognizes Israel as a State, nor does it maintain any diplomatic relations with the only Jewish country in the world.

When in May 2021 the issue of removing the five decades long travel prohibition clause from the new e-passport came to the fore, Bangladesh FM's immediate reaction was that his Ministry's predicament from a diplomatic perspective is "nothing unique" in dropping the words "except Israel" from the declaration of validity of the Bangladesh passport and that "the move has made him and his ministry face questions that are quite intriguing and not so easy to brush aside" (Ahmed, 2021).

It is apparent from the instantaneous retort by the Foreign Minister that the decision that potentially carries pressing relevance to the country's foreign policy strategies, was not taken by the Ministry of Home Affairs (MoHA), the responsible Ministry for passport and immigration, following any formal consultation with its concerned counterparts, nor was the issue placed before the Parliament or other public fora for discussion. The fundamental right to movement, including the right "to leave and re-enter Bangladesh", is protected by the Constitution of the country subject to "any reasonable restrictions imposed by law in the public interest" (Article 36, Bangladesh Constitution). Ideally, it is under-

${ }^{1}$ The Supreme Court of Bangladesh observed that Article 25 of the Constitution "casts an obligation upon the State to have respect for international law and the principles enunciated in the United Nations Charter". Professor Nurul Islam et al. vs Government of the People's Republic of Bangladesh et al. 52 DLR (2000) 413. 
stood that "public interest" embraces issues of foreign policy and international relations of the country, and that any change or interference with this constitutional right is the jurisdictional mandate of the legislature as peoples' representative. However, as discussed earlier under the section on relevant legal provisions, this authority has been delegated to the Executive Branch by a legal instrument (see, e.g. Capassakis, 1981). ${ }^{2}$

Following the public exposure of the policy change, especially facing the media questions based on a message posted on the officially verified Facebook page of the Israeli Ministry of Foreign Affairs, the Bangladesh FM mentioned that he immediately discussed the issue with the Home Minister and was told that the decision was already taken at the end of last year (i.e. 2020) and currently being implemented for issuing the new e-passports. As noted by BBC Bangla (24 May, 2021): "[I]t indicates that this was done without any assessment of any political fallout or legal consequences."

\subsection{International Practices with Regard to Travel Ban}

While responding to the media on making such a significant policy departure, the FM noted that six months ago the Home Ministry had reviewed several other national passports before taking the decision. It is not, however, clarified whether the Home Ministry reviewed the "other passports" randomly representing both sides of the policy in this regard, or only those that have diplomatic tie with Israel, and hence provide no restriction or prohibition on travel to Israel in their passports.

The Home Minister also commented that " $[\mathrm{N}] \mathrm{o}$ country uses the words anymore, not even the Arab nations ... You must have diplomatic relations (for travel)" (bdnews24.com, 23 May 2021b). This statement seems ambiguous and factually unfounded. Firstly, at least five other countries' passports explicitly contain similar exclusion clause prohibiting travel to Israel, such as Pakistan, Malaysia, Brunei, Iran and Iraq (Shah, 2020). Also, Libya, that does not even recognise the existence of Israel, states in its passports: "All countries of the world except occupied Palestine" (Mohsin, 2021).

Secondly, the Government of Malaysia that includes the exclusion clause on the first page of its e-passport, and has no diplomatic tie with Israel, still permits limited travel to Israel under certain terms and conditions that include: conference, meeting, and religious reasons (for Muslims and Christians). As it is understood from the statement of the Ministry of Foreign Affairs in Bangladesh (using the phrase "without Government permission" while clarifying the travel ban), windows for similar exceptions in allowing travel to Israel are also open for Bangladeshi nationals subject to prior approval by the concerned authority, although no particular grounds in this regard have so far been specified by the Government.

On the other hand, in the context of diplomatic and international relations, ${ }^{2}$ For the constitutionality of such delegation, see Kent v. Dulles, 357 U.S. 116, 129 (1958). 
there are thirteen countries that do not accept Israeli passports, namely, Algeria, Bangladesh, Brunei, Iran, Iraq, Kuwait, Lebanon, Libya, Malaysia, Pakistan, Saudi Arabia, Syria, and Yemen (Mohsin, 2021). Some of these countries also do not accept passports that have an Israeli visa endorsed. Some countries also ban direct flights and over flights to and from Israel. Out of the $28 \mathrm{UN}$ member states who do not recognize legitimacy of Israel as a "State", 15 are members of the Arab League and ten from the OIC. Currently, of the 193 member states of the United Nations, 138 (71.5\%) including Bangladesh have recognised the State of Palestine (World Population Review, 2021).

Another relevant point of view is that a government declaration in the national passport prohibiting travel to a particular country is not only a part of the terms and conditions upon which the passport is issued; more significantly, it represents and re-enforces the concerned government's foreign policy with regard to such "prohibited" states. The early $20^{\text {th }}$ century Anglo-Persian dispute over the Bahrein Islands that continued for several decades is an instance where the United Kingdom, in exercising its control over the Islands against Persian territorial claim, required Persian nationals to produce a passport to enter the Bahrein territory treating them as foreigners (see, Turack, 1971; also, Kelly, 1957). Similarly, the centuries-old Spanish-British territorial and diplomatic controversy over Gibraltar (since the 1704 War of the Spanish Succession) that to some extent continues to-date involved measures and counter-measures regarding validity of passports and travel documents. Spain's action in 1965 of accepting some British passports issued by her Majesty but not those endorsed by the British Consul in Spain illustrates the instance, "a policy similar to that of the Russian Czarist Government with respect to the American passports held by naturalized American citizens of the Jewish faith" (Bentwich, 1912 referenced in Turack, 1971).

However, the existence of any specific travel declaration in the passport becomes irrelevant if by virtue of a changed state policy due to certain supervening reasons, citizens are prohibited from travelling to a certain country (such as on security or public health grounds). Similarly, nationals of specified countries, or certain individuals or groups from those countries, may be prohibited from travelling to the declaring state as part of international sanctions or collective action. For instance, members of autocratic military junta, or persons accused of gross violation of human rights, war crime or crimes against humanity are often barred from travelling to the US or the EU.

Again, modern day passport may also be seen as one that implies the characters of an international treaty which, in addition to the assurance of protection and security extended to the holder of the passport by the issuing national authority (Diplock, 1946), also represents an agreement between States to protect certain rights of the bearer including entry and exit (subject to visa and other requirements), applicable privileges and immunities (if any), etc. Matters of foreign policy and bilateral relations between two or more countries are thus inherently embedded in the concept of developing modern passports. 
From a different perspective, in the present scenario, if "whatever is written or omitted in the passport" is irrelevant (as maintained by the GoB in the given context) and all that matters is the policy standing in the country's international relations (with Israel in this case), why in the first place was it necessary to include a travel ban on three specific destinations (South Africa, Taiwan and Israel) in the original Bangladesh passport? Later, on two separate occasions, why was it necessary to remove the bar from South Africa (justifiably) and Taiwan (with unclarified diplomatic silence)? Similar questions may be raised with regard to the linkages between diplomatic tie and travel authorization, as in the Bangladesh-Taiwan instance (travel ban lifted but still no diplomatic relation). What is contended in the argument above is the fact that the words contained in a passport are important, but not as much as the policy stance of the state concerned.

\subsection{Maintaining "International Standards" and "Administrative Convenience"}

Regarding the travel ban issue, Bangladesh Foreign Minister commented that the decision to drop the phrase "except Israel" from newly issued e-passports is made to maintain its "international standard" that created a speculation that Bangladesh lifted the travel ban to Israel. The Minister further added: "The passport is an identity and it doesn't relate to foreign policy". A similar statement was made by the Director General of the Department of Immigration and Passports: "Passports only carry important information pertaining to the holder... Nothing is more important than that" (Tribune Report, 2021). While for the sake of agreeing with the Foreign Minister's first proposition one may assume that what the Minister implied is that a passport is an individual's identity endorsed on his travel document to be used for his or her overseas travel, the latter part of the statement does not seem well founded.

The New Oxford Companion to Law (2008) defines a passport as "a travel document, usually issued by a country's government to its citizens, that certifies the identity and nationality of its holder primarily for the purpose of international travel" (Passport Index, n.d.). The word passport is a combination of the French words passer (to pass) and porte (a port or gate), a formal document that people in medieval Europe used to present while passing through the gates of city walls (Hagedorn, 2008).

However, the consistent global practice of issuing a national passport for citizens is a relatively modern development. While "Letter of Transit" or other forms of identity and travel documents were used for centuries for transborder movements, modern day passports-a $19^{\text {th }}$ and $20^{\text {th }}$ century innovation-have increasingly become a crucial part of a country's foreign policy (Britannica, 2016). International law also recognizes passports as an "official document" issued to offer some proof of the bearer's identity and nationality, and "to cross international boundaries" (Hagedorn, 2008; also, Muchmore, 2004). Professor Salter (2003), who traces the history of the passport within the context of international 
relations, observed that a national passport is an integral element of the right to international passage and "a central feature of international relations." Thus, for instance, the US Supreme Court in Zemel v. Rusk observed that traveling abroad "can have a direct impact on foreign policy by involving the United States in 'dangerous international incidents"' (see also, Schwartz, 1979).

With regard to "international e-passport standards" it may be noted that guidelines on international standards for biometric e-passports are provided by the International Civil Aviation Organization (ICAO) based in Montreal, Canada (ICAO, 2012). In Bangladesh, Introduction of Bangladesh e-Passport and Automated Border Control Management Project under the Department of Immigration and Passports (DIP) is being implemented by the German company Veridos $\mathrm{GmbH}$ in association with Bangladesh Army (German Embassy Dhaka, 2021). All ICAO standards and approved guidelines are being followed in the implementation of the project.

In fact, there are no provisions in the relevant international standards and guidelines against inclusion of a travel restriction declaration in the e-passports. Thus, for instance, the national e-passport of Malaysia that currently ranks on the 14th place according to the "Guide Passport Ranking Index" provides visa-free access to 180 countries (Visa Index, 2021). It would be literally perplexing to argue that the Malaysian e-passport (that contains identical travel prohibition on Israel as in the Bangladesh MRPs) is not in compliance with the "international standards".

The Foreign Ministry further commented that the Changes in the travel ban declaration are made for "administrative convenience" without clarifying what this convenience signifies. Because of the use of the term "administrative", one may reasonably assume that it is due to the work-order already issued to the German company for the booklets with the chips that do not contain the two-word prohibition. Such an assumption may be further supported by the fact that the country simultaneously endorses two types of passports, the MRP containing the travel ban, and the "being implemented" e-passport that removes the words of prohibition.

There are also contradictory statements by the officials of the two Ministries. Thus, while the Foreign Ministry holds that despite the removal of the "two-word" phrase from the e-passports does not make any change in allowing a Bangladesh national to travel to Israel, one official of the same Ministry, who preferred anonymity, told $\mathrm{Al}$ Jazeera that none of the passport and immigration acts can stop a Bangladeshi person from visiting Israel after the change (Mahmud, 2021).

Again, as noted above, while the Foreign Ministry categorically asserted that the step has been taken only to bring the new e-passport in compliance with international standards, Director General of the Department of Immigration and Passport (Ministry of Home) commented that this step has "no link with the country's diplomatic relations with any other country" and that the holder of the

${ }^{3}$ Zemel v. Rusk, 381 U.S. 1, 15 (1965). 
passport "can travel anywhere if you have visa of that country" (Star Digital Report, 2021a).

To summarise the sub-sections above, despite the statements by the government agencies justifying the removal of the travel ban phrase from Bangladesh passports on "administrative convenience" or "international standard" grounds, some of which are seemingly contradictory and lead to "intriguing questions" for the Government, there are obvious implications of the move on the country's foreign policy stance in relation to Israel, more broadly to the complex geo-politics in the Middle East.

\section{Removal of the Prohibition Clause: Road to a Revised Israel Policy?}

As the travel ban issue raised national and international concerns, Bangladesh FM repeatedly claimed that there has been no change in the country's position towards Israel as it still does not recognise Israel and would not do so until an independent state of Palestine is established (UNB News, 2021). The Foreign Ministry statement noted: "Bangladesh reiterates its principled position concerning the 'Two-State Solution' of the Palestine-Israel conflict in light of the UN resolutions recognising pre-1967 borders and East Jerusalem as the capital of the State of Palestine" (Star Digital Report, 2021b).

There is a strategic question involved in the Ministry's standpoint. If recognition of Israel is subject to the establishment of an independent Palestine as per the pre-1967 borders (including East Jerusalem), then the complexity arises as to which territories does Bangladesh imply to be restored to Palestine from Israel? ${ }^{4}$ Is this the territory as per the 1947 Partition Plan, ${ }^{5}$ the territories as they stood during 1949-1967 period, or the present "occupied Palestinian territories" as shown in Figure 1? It may be noted that the present "occupied territories" include Gaza, the West Bank and East Jerusalem, the longest occupation in modern history, that have been under Israeli military control since 1967 (Haddad, 2020). There are of course numerous complex, unresolved questions of international law, diplomacy and geo-political issues involved that are not within the scope of this article.

There are two dimensions of the comment made by the Bangladesh Foreign Minister (stated above): one, it is still possible to travel to Israel if the government permits. Here is also another ambiguity. Every person needs clearance from the Immigration Department at the point of departure to travel abroad. In other words, government permission is required for travelling to any country. One may thus identify a difference between the position earlier (with the two-word phrase still in existence) when government permission was not in

${ }^{4}$ They key disputed issue relates to the boundary between the two states; while both Palestine and the Arab leadership insist on the " 1967 borders", Israel continues to refuse the claim.

${ }^{5}$ The Partition Plan was a proposal by the UN (Resolution 181/1947) that recommended a partition of Mandatory Palestine into independent Arab and Jewish States. It was rejected by the Palestinians, leading to a civil war and the end of the British Mandate. 

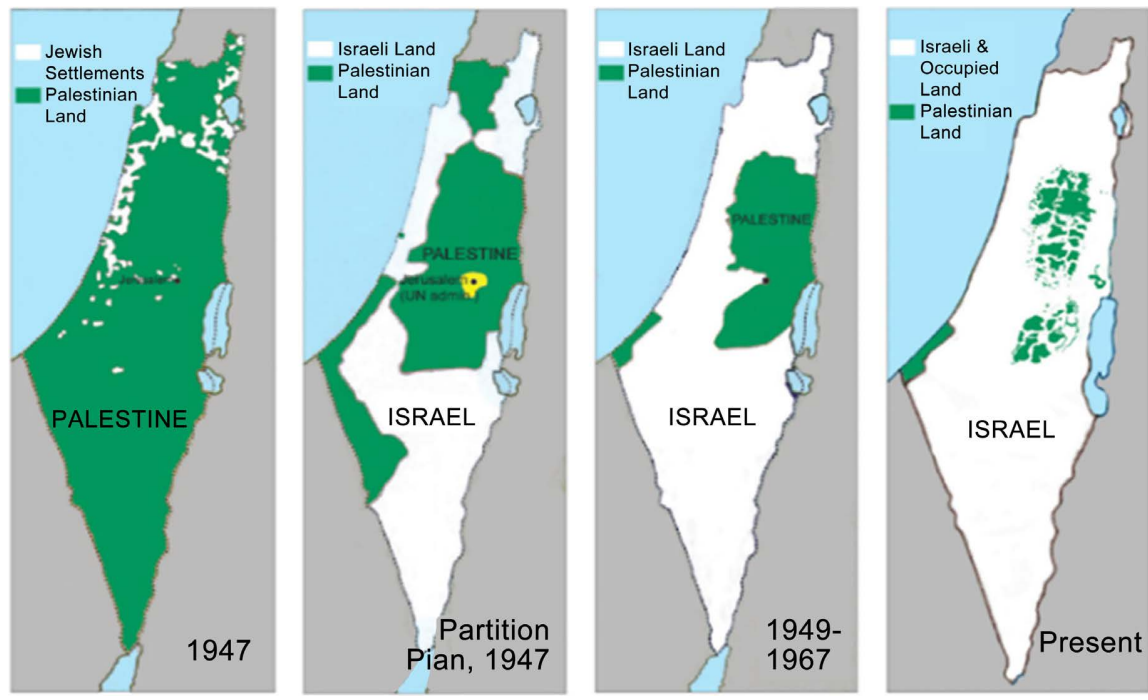

Figure 1. Palestinian loss of land 1947 to present. Image Source: GUE/NGL (Internet).

discussion as there was a clear prohibition on travelling to Israel, and the current position when the government (according to its statements) retains a discretion to permit the travel or not.

The second dimension relates to travel prohibition and diplomatic relations. Bangladesh's foreign policy regarding Israel clearly states that Israel is not recognised by Bangladesh as a State and the territories that Israel claim to be its own belong to Palestine. In other words, except the territory divided between Israel and Palestine in 1947 under the UN initiative, all other occupied territories by Israel belong to Palestine. What if a Bangladesh national enters any part of such territories from Jordan or Lebanon relying on the position that this is legally a Palestinian territory?

The statements by the Ministry of Foreign Affairs indicate that immigration clearance or embarkation at the exit point in Bangladesh will be refused if a Bangladeshi national attempts to travel to Israel. There is no specific mention about obtaining an Israeli visa from a third country, and apparently Israeli authorities will be willing to issue visas for Bangladeshi nationals as evident from the tweet made by the Israeli Foreign Ministry immediately after the declaration by the Government of Bangladesh regarding removal of the prohibitive phrase from the passport. Would someone be brought under punitive action if a visa application is filed, or the visa is obtained, from an Israeli Embassy (but the actual travel has not been done)? There are complex legal and technical issues involved in addressing these questions.

Thus, for instance, although Bangladesh does not recognise the statehood of, nor maintain any official diplomatic relations with, Taiwan or Northern Cyprus (since 1983 amid international pressure when Bangladesh withdrew its Northern Cyprus recognition following the UNSC Resolution 541), Bangladeshi nationals can obtain a visa and travel to both the countries; there are also bilateral trade and economic activities between them. 
From the perspectives of international law, although there is a scarcity of normative provisions regarding the foregoing and other strategic issues related to the treatment and regulation of passports by national authorities, prima facie there is now no bar on Israel in issuing visa or admitting Bangladesh nationals to its territory. This is implied in the statement tweeted by the Deputy Director General for Asia and the Pacific at the Israeli Ministry of Foreign Affairs Gilad Cohen: "Great news! ... I call on the Bangladeshi government to move forward and establish diplomatic ties with Israel so both our peoples could benefit and prosper" (Cohen 2021). Also, the Israeli Ambassador to India noted: "[L]ook forward to working with the Government of Bangladesh, so much added value we can bring to each other" (Mohsin, 2021). Even for passports that contain a prohibition clause (such as the Bangladesh MRPs that are still valid, or other countries' passports), Israeli Immigration may still allow the holders to enter Israel, as well as for passports of countries that refuse entry to their country if there is a travel history to Israel. In fact, strategically, Israeli Immigration refrain from stamping all such passports with an entry seal. Instead, they issue a "loose-leaf" document (called "entry card") that is discarded at the time of exit from Israel, and thereby provides a "safety" to the traveller by avoiding "any evidence of travel to Israel" (Zaino, 2019).

Hypothetically, in a plain logical thought, a country cannot actually allow, or prohibit, travelling to a country that seen through its foreign policy lens even doesn't exist. From that perspective, without having to revisit the complex questions of "statehood" in international law, many may argue that while Bangladesh's declaration in the passport for fifty years prohibiting travel to "Israel" implied an indirect recognition of its existence in the geography of the world, now the removal of the phrase appears to be a further step forward reinforcing the concomitant concession. The critical question, even if from an academic point of view, relates to the possibilities of eventual development of bilateral relations, recognition of Israel's statehood and diplomatic ties not precluded, between the two nations.

From the Israeli point of view, however, such assumptions are very unlikely to bear any significance as the country's statehood is an accepted fact in the UN (holding majority support in favour) and, in legal terms, by the application of Article 3 of the Montevideo Convention on the Rights and Duties of States, 1933: "The political existence of the state is independent of recognition by the other states." To be fair, however, the same arguments may also be made with regard to Palestine.

Ambiguities thus exist between the statements made by different responsible agencies of the Government of Bangladesh in this regard. Does the removal of the phrase now mean that if a Bangladeshi national travels to a country that has diplomatic tie with Israel, applies for a visa at the Israeli Embassy and obtains the visa, he can lawfully travel to Israel? According to an Immigration Officer in Dhaka under anonymity, this is certainly a possibility (Mahmud, 2021).

Again, it is clear from the wording of the prohibition clause in the previously 
issued MRPs that the declaration renders the passport invalid for an attempt to travel to Israel; in other words, the restriction relates to the validity of the passport, not the citizen concerned (for instance his or her citizenship is not invalidated). What about a Bangladeshi with a dual citizenship of USA (by obtaining the required Dual Nationality Certificate from Bangladesh) travels to Tel Aviv from Washington DC using his US passport and then comes to Dhaka showing his Bangladesh passport? Would he be arrested or prosecuted in Bangladesh for travelling to Israel although he did not use his Bangladesh passport for exiting the US or entering the Israeli territory?

Further, "no change in Bangladesh's position towards Israel" implies Bangladesh's non-recognition of the State of Israel. This policy stand clearly implies that there will be no diplomatic or other bi- or multilateral relations between the two countries including trade and business, bilateral economic, educational, cultural and other agreements and international collaboration, etc. However, it has been reported by local and international media based on government statistics that over the recent past years, direct and indirect trade relations between the two countries have been in steady growth.

Thus, for instance, at the multilateral trade promotion platform, Bangladesh and Israel are both members of the World Trade Organization (WTO). At the bilateral level, official statistics for 2019-20 released by Bangladesh Export Promotion Bureau (EPB located within the ministry of Commerce) shows that Bangladesh exported various goods worth just over USD 28,000 to Israel, while the Bangladesh Bureau of Statistics (Ministry of Planning) data depicts that Bangladesh's export to "New Israel" ${ }^{\circ}$ during 2019-20 was around US $\$ 331,000$ (BBS, 2021). A compiled data from EPB also demonstrates that in the last one decade, total export from Bangladesh stood at around half a million USD that included textile, ready-made garments and pharmaceutical products (Kibria, 2021). However, the statistics provided by the government agencies in Bangladesh show some discrepancies with the database of the World Bank's "World Integrated Trade Solution (WITS) database" that showed that during 2010-18, Israel imported products worth around \$333.74 million from Bangladesh (Kibria, 2021).

On the other hand, in terms of Bangladesh's import from Israel, WITS data shows that between 2009 and 2015 it stood at $\$ 3.67$ million, while no data is available after 2015 in the WITS system. Data provided by the central bank of Bangladesh (Bangladesh Bank) also does not have any information on Bangladesh's imports from Israel. However, an $\mathrm{Al}$ Jazeera investigation reported that in 2018 Bangladesh has purchased highly sophisticated spyware (cell phone surveillance equipment) developed by the Israeli cyber-surveillance company PicSix using a Bangkok-based middleman and that Bangladeshi personnel were trained

${ }^{6}$ Operating since 1979, the New Israel Fund is a U.S.-based non-profit organization. Being the largest donor to progressive causes in Israel, its objective includes social justice and equality for all Israelis. See, “New Israel.” Merriam-Webster.com Dictionary, Merriam-Webster,

https://www.merriam-webster.com/dictionary/New\%20Israel. 
on these equipment in Hungary conducted by Israeli experts (Al Jazeera Investigative Unit, 2021).

Apart from bilateral trade and economy, Bangladesh's interests in relation to Israel involve multiple other areas including Israel's highly sophisticated technology domain and state-of-the-art military armaments. One priority area of concern for Bangladesh relates to the neighbouring State of Myanmar that poses the key threat to Bangladesh's physical security in the region. According to the 2018 report published by a U.N. fact-finding mission (Darusman, 2018), Israel was among the seven countries that supplied Tatmadaw (Myanmar Armed Forces) with weapons of mass destruction that were used in launching a series of attacks in 2017 against the Rohingya Muslims in Myanmar's Rakhaine State (formerly Arakan), forcing around 800,000 refugees to flee across the border into Bangladesh (Ye, 2019). In November 2016, shortly after Bangladesh purchased two Chinese-made submarines to become only the second nation in the Bay of Bengal with under-sea arsenals, Israel Aerospace Industries, the state-owned aerospace and aviation manufacturer, delivered two attack frigates to Myanmar' (see Jha, 2016).

Although the maritime boundary disputes between Myanmar and Bangladesh were settled in 2012 through international arbitration, tensions between these two neighbouring nations still exist. Thus, while obtaining intelligence about Israel's interaction with the Myanmar Military Junta is of critical strategic importance for Bangladesh, it is also a defence prerogative for the country to side-track Israel from engaging in arms deals with Myanmar. From Israel's point of view, on the other hand, securing even a back-channel recognition from Bangladesh will be considered to be a major symbolic victory in the global governance front. As noted by Kabir (2021) in this context: "Following recent ... economic and social indexes, Bangladesh is emerging as a leader in the Muslim world and must be an increasingly attractive partner for Israel."

A major concern for Bangladesh in recognizing the statehood or establishing formal or informal relations with Israel relates to the way its Arab and Middle Eastern counterparts are expected to react to such a move. This is of crucial importance for Bangladesh as the Arab nations host the largest numbers of migrant workers from Bangladesh, second highest source of the country's remittance earning (after RMG). Thus, along with Jordan and Egypt that already recognised Israel, the year 2020 saw the acceptance and recognition of the Hebrew nation by the UAE, Bahrain, Sudan and Morocco. The Gulf giant Saudi Arabia that itself hosts almost $32 \%$ of total migrant workers from Bangladesh is also adopting a "non-conflict", "soft normalisation" policy towards Israel (TRT World, 2020).

From the foreign policy perspectives of both Bangladesh and Israel, the factors stated above (along with international influence and persuasion from Bangladesh's Western allies) reinforced by the recent move of removing the travel ban clause from Bangladesh passports naturally lead to several speculative assertions. What lies at the core of this policy conundrum is the possibility of developing bilateral ties between the two nations, at least by "back-channel diplomacy", i.e. 
continuing "a clandestine but mutually beneficial working relationship", to start with (TRT World, 2020).

To summarise, statements from the concerned government agencies that the foreign policy posture of Bangladesh has not been changed by the recent move and that Bangladesh continues to stand by its principled position concerning the "Two-State Solution" of the Palestine-Israel conflict call for further clarification. Thus, for instance, there remains the complex question of which territory (pre/post-1967, or the present occupied Palestinian territories) will be considered as Israel in relation to the travel ban.

Undeniably, to the least, the removal of the two-word prohibition now opens up the possibility for Bangladesh passport holders to travel to Israel with prior government approval. From that perspective, an obvious difference has been made between the country's previous position (an absolute prohibition on travel to Israel) and the new, changed circumstance (a relative prohibition with a discretion on the part of the Government in permitting such travel). Also, international media reports and other sources indicate to a steady growth of direct and indirect trade and economic relations between the two countries as well as to issues of regional defence prerogative and strategic security interests on the part of Bangladesh (especially in the context of its on-going refugee and border issues with Myanmar, and Myanmar-Israel military arsenal collaboration). From academic perspectives, these and several other complex technical issues essentially imply significant questions of law and diplomacy.

\section{Conclusion}

A diversity of thoughts and speculations has developed around the issue of removing the prohibition clause in Bangladesh passports that declared the passport to be invalid for travelling to Israel. Many legal experts have opined that according to the Government of Bangladesh statements, it would be illegal for a Bangladeshi to travel to Israel from Bangladesh. However, if the same person travels to Israel from a third country, Israel (or a transit country en route) might not see a reason to stop him as the passport now (apparently) doesn't stop him from travelling to Israel.

The above argument, however, wouldn't be valid if there is a law in the form of a legislative enactment or executive Order or Rule to the effect that the passport issued by the Government of Bangladesh prohibits its holder (while as per the passport laws of the land, Bangladesh remains the owner of the document) from travelling to Israel and that any contravention thereof, or an attempt thereto, shall be as punishable as per law. Several laws exist in Bangladesh that serve as the bases for the Government move in making the change in the country's newly introduced e-passports, some of which as old as fifty to hundred years old, and hence need to be updated. Also, it is specifically required by the existing laws that any such decision must be made public by publishing them in the official Gazette Notification of the Government that apparently was not fol- 
lowed.

It has been noted in the present paper that the statement of the Ministry of Foreign Affairs in Bangladesh using the phrase "without Government permission" while clarifying the travel ban clearly indicates that the Government may, at its discretion, allow travel to Israel despite its policy stance of non-recognition of the country, although no particular grounds for such authorization have so far been specified. Further, contradictory statements from different concerned Ministries regarding the legal consequences of removing the prohibitive travel declaration, and its interaction with the country's foreign policy and broader international relations, have led to ambiguities and confusions both nationally and internationally. In this context, the Palestinian Ambassador in Dhaka in his reaction over the issue expressed his discontent to the local media that the omission of the words "except Israel" from Bangladeshi passport is "unacceptable" (Kamruzzaman, 2021). In fact, this is where the law and diplomacy in Bangladesh have been placed face-to-face over an issue involving mass public sentiment inasmuch as across the board in international colloquy.

As contended in the foregoing discussion, words contained in a passport are unquestionably important (such as the travel ban or its removal), but not as much as the policy stand of the state concerned in matters of foreign relations and policies that reflect and reaffirm its national interests, values, self-perception and aspirations. This argument is further supported by the co-existence of two formats of passports (e-passport along with the MRPs valid up to their expiry) one containing the declaration of travel ban whiles the other removing it.

Finally, the decision to remove the two words was made at the end of 2020 when US-backed efforts towards Israel-Arabs reconciliation saw some lights ahead of the much talked about US presidential election, and later, the declaration of the move was made (May 2021) at a time when several other nations (UAE, Bahrain, Morocco, Sudan and Bhutan) extended their recognition to Israel. Al these factors, along with the reality of increasing growth in trade and business between Bangladesh and Israel in the last few years have raised "intriguing questions" that cannot be "brushed aside". To conclude, the complexities arising out of the issue and the absorbing global attention raised render the Bangladesh-Israel travel ban controversy a textbook case in both legal and diplomatic studies.

\section{Conflicts of Interest}

The author declares no conflicts of interest regarding the publication of this paper.

\section{References}

Ahmed, J. (2020). The Theoretical Significance of Foreign Policy in International Relations-An Analysis. Journal of Critical Reviews, 7, 787. http://www.jcreview.com/fulltext/197-1583132694.pdf

Ahmed, K. (2021) Why Removing "Except Israel” from Passport Is Problematic. The 
Daily Star, 27 May 2021.

https://www.thedailystar.net/opinion/news/why-removing-except-israel-passport-prob lematic-2099349

Al Jazeera Investigative Unit (2021). Bangladesh Bought Mass Spying Equipment from Israeli Company. Al-Jazeera, 2 Feb. 2021.

https://www.aljazeera.com/news/2021/2/2/bangladesh-bought-surveillance-equipmentfrom-israeli-company

BBS (2021). Foreign Trade Statistics of Bangladesh 2019-20 (p. 37). National Accounting Wing, Bangladesh Bureau of Statistics, Ministry of Planning, Government of Bangladesh (April 2021).

http://bbs.portal.gov.bd/sites/default/files/files/bbs.portal.gov.bd/page/8643ec8b 27a3 41cd bbd9 9be3479f578e/2021-05-16-07-23-44bf174e4067f2379fa65c6b7dbefb52.pdf

bdnews24.com (2021a). Bangladeshis Will Be Prosecuted If They Travel to Israel, Says FM Momen. 26 May 2021.

https://bdnews24.com/bangladesh/2021/05/26/bangladeshis-will-be-prosecuted-if-they -travel-to-israel-says-fm-momen

bdnews24.com (2021b). Bangladesh Dropping "Except Israel” from Passports: What the Government Says. Diplomatic Correspondent, 23 May 2021.

https://bdnews24.com/bangladesh/2021/05/23/bangladesh-dropping-except-israel-fro m-passports-what-the-government-says

Bentwich (1912). Russian Passport Question. 98 Fortnightly Rev. 517.

Britannica, The Editors of Encyclopaedia (2016). Passport. Encyclopaedia Britannica, 24 May 2016. https://www.britannica.com/topic/passport

Britannica, The Editors of Encyclopaedia (2021). Two-State Solution. Encyclopedia Britannica, 20 May 2021, https://www.britannica.com/topic/two-state-solution

Capassakis, E. (1981). Passport Revocations or Denial on the Ground of National Security and Foreign Policy. Fordham Law Review, 49, 1178-1196.

https://ir.lawnet.fordham.edu/flr/vol49/iss6/12

Cohen, G. (2021). Tweet. 22 May 2021.

https://twitter.com/giladcohen/status/1396155072392933378

Council of Europe (2013). The Right to Leave a Country. Issue Paper: Council of Europe. Commissioner for Human Rights.

https://rm.coe.int/the-right-to-leave-a-country-issue-paper-published-by-the-councilof-e/16806da510

Darusman, M. (2018). UN. Human Rights Council. Independent International Fact-Finding Mission on Human Rights in Myanmar (2018). United Nations Digital Library System, 22 October 2019. https://digitallibrary.un.org/record/3871358? $\ln =\mathrm{en}$

Diplock, K. (1946). Passports and Protection in International Law. Transactions of the Grotius Society, 32, 42-59. https://www.jstor.org/stable/743187

Fahad, A. M. (2021). Foreign Policy of Bangladesh: A Very Simple Idea. academia.edu. https://www.academia.edu/376518/Foreign policy of Bangladesh a very simple idea

Faris, N. A., Fraser, P. M., Kenyon, K. M. et al. (2021). Palestine. Encyclopaedia Britannica, 11 May 2021. https://www.britannica.com/place/Palestine

Frankel, J. (1963). The Making of Foreign Policy: An Analysis of Decision Making (p. 1). Oxford University Press. https://www.jstor.org/stable/41231166?seq=1

German Embassy Dhaka (2021). Press Release: e-Passport and Automated Border Control Management. 22 January 2021.

https://dhaka.diplo.de/bd-en/topics/wirtschaft/-/2294738 
Haddad, M. (2020). Palestine and Israel: Mapping an Annexation. Al-Jazeera, 26 Jun 2020.

https://www.aljazeera.com/news/2020/6/26/palestine-and-israel-mapping-an-annexati on

Hagedorn, C. (2008). Passport. Max Planck Encyclopedias of International Law. Oxford Public International Law: Oxford.

https://en.wikipedia.org/wiki/Bangladesh\%E2\%80\%93Taiwan relations

ICAO (2012). International E-Passport Standards. In Eight Symposium and Exhibition on ICAO MRTDs, Biometrics and Security Standards. ICAO MRTD Report. International Civil Aviation Organization. Vol. 8, Montreal, Canada. https://nonews.co/wp-content/uploads/2016/06/mrtd report vol8 no1.pdf

Jha, S. (2016). The Bay of Bengal Naval Arms Race. The Diplomat, 30 December 2016. https://thediplomat.com/2016/12/the-bay-of-bengal-naval-arms-race

Kabir, A. (2021, March 1). Is Bangladesh Moving to Normalize Relations with Israel? Nikkei Asia.

https://asia.nikkei.com/Opinion/Is-Bangladesh-moving-to-normalize-relations-with-Is $\underline{\text { rael }}$

Kamruzzaman, M. (2021). Confusion as Bangladesh Drops “Except Israel” from New Passports. AA News, 24 May 2021.

https://www.aa.com.tr/en/asia-pacific/confusion-as-bangladesh-drops-except-israel-fro m-new-passports/2252088

Kelly, J. B. (1957). The Persian Claim to Bahrain. International Affairs, 33, 51-70. https://doi.org/10.2307/2604468

Kibria, A. (2021). Time to Decode Bangladesh-Israel Trade. The Financial Express, 27 May 2021.

https://thefinancialexpress.com.bd/views/time-to-decode-bangladesh-israel-trade-1622 $\underline{130558}$

Mahmud, F. (2021). Bangladesh Removes Passport Clause That Barred Travel to Israel. Al-Jazeera, 27 May 2021.

https://www.aljazeera.com/news/2021/5/27/bangladesh-drops-except-israel-from-pass ports-creates-confusio

Ministry of Law, Justice and Parliamentary Affairs (Legislative and Parliamentary Affairs Division) (n.d.). Laws of Bangladesh. http://bdlaws.minlaw.gov.bd

Mohsin, S. (2021). Why Remove "Except Israel” from Passports? The Daily Star, 31 May 2021.

https://www.thedailystar.net/opinion/news/why-remove-except-israel-passports-21017 $\underline{85}$

Muchmore, A. I. (2004). Passports and Nationality in International Law. U.C. Davis Journal of International Law \& Policy, 10, 301.

Passport Index (n.d.). Everything You Need to Know about Passports. https://www.passportindex.org/passport.php

Salter, M. B. (2003). The Rights of Passage: The Passport in International Relations. Lynne Rienner Publishing.

Schwartz, B. (1979). Constitutional Law (2nd ed.). 3.15 at 100.

Scott, P. (2020). Passports, the Right to Travel, and National Security in the Commonwealth. International and Comparative Law Quarterly, 69, 365-395.

https://doi.org/10.1017/S0020589320000093

Shah, S. (2020). 30 Countries, Including Pakistan, Still Do Not Recognize Israel. The 
News International, 22 August 2020.

https://www.thenews.com.pk/print/704227-30-countries-including-pakistan-still-do-n ot-recognise-israel

Star Digital Report (2021a). Removing "Except Israel” in New Passport Doesn't Mean Bangladesh's Position Changed: Momen. The Daily Star, 23 May 2021.

https://www.thedailystar.net/bangladesh/news/removing-except-israel-new-passport-d oesnt-mean-bangladeshs-position-changed-momen-2097313

Star Digital Report (2021b). Travel Ban Remains: Dhaka Reacts to Israel Foreign Ministry's Tweet. The Daily Star, 23 May 2021.

https://www.thedailystar.net/bangladesh/news/travel-ban-remains-dhaka-reacts-israelforeign-ministrys-tweet-2097473

The Jerusalem Post (2021). Twitter, 23 May 2021. https://twitter.com/Jerusalem Post/status/1396377595739058177

Tipu, M. S. I. (2014). Mysterious Salah Uddin Shoaib Gets 7-Year Jail. Dhaka Tribune, 9 January 2014.

https://www.dhakatribune.com/uncategorized/2014/01/09/mysterious-salah-uddin-sho aib-gets-7-year-jail

Tribune Report (2021). Bangladesh Drops “Except Israel” from Passport, But Keeps Ban on Travel. Dhaka Tribune, 23 May 2021.

https://www.dhakatribune.com/bangladesh/foreign-affairs/2021/05/23/bangladesh-dro ps-except-israel-from-passport

TRT World (2020). Saudi Arabia Adopts "Soft Normalisation" with Israel. 24 September 2020.

https://www.trtworld.com/magazine/saudi-arabia-adopts-soft-normalisation-with-isra el-40030

Turack, D. C. (1971). Selected Aspects of International and Municipal Law Concerning Passports. William and Mary Law Review, 12, 805.

https://scholarship.law.wm.edu/cgi/viewcontent.cgi?article=2758\&context=wmlr

UNB News (2021). No Change in Bangladesh's Position over Israel: FM. 23 May 2021. https://unb.com.bd/category/Bangladesh/no-change-in-bangladeshs-position-over-isra el-fm/70536

Visa Index (2021). Malaysia Passport Ranking. https://visaindex.com/country/malaysia-passport-ranking

Wikipedia (2021). Bangladesh-Taiwan Relations. 25 January 2021.

World Population Review (2021). Countries That Recognize Palestine 2021. https://worldpopulationreview.com/country-rankings/countries-that-recognize-palesti $\underline{\text { ne }}$

Ye Lynn, K. (2019). 7 Countries Still Supplying Arms to Myanmar Military. AA News, 5 August 2019.

https://www.aa.com.tr/en/asia-pacific/7-countries-still-supplying-arms-to-myanmar-m ilitary/1550371

Yeasmin, S. (n.d.). The 15th Amendment of the Constitution and the Confrontational Politics. academia.edu.

https://www.academia.edu/29363795/The 15th amendment of the constitution and the confrontational politics

Zaino, L. (2019). Before You Go: What to Know about Entering and Exiting Israel. The Points Guy, 13 June 2019.

https://thepointsguy.com/guide/israel-entry-exit-travel-requirements 